\title{
PERAN HUMAS PEMBENTUK OPINI PUBLIK DALAM UPAYA PENCITRAAN LEMBAGA PENDIDIKAN
}

\author{
Patrea Reola Pramungkas \\ Universitas Nurul Jadid \\ E-mail: Patrearana28@gmail.com
}

\begin{abstract}
Abstrak
Keberadaan manajemen public relations sangat penting dalam suatu lembaga pendidikan terutama dalam komunikasi dengan masyarakat untuk membentuk suatu opini yang baik. Pendidikan adalah sumber investasi terbesar dalam mengembangkan dan membuat orang utuh (insanul kamil). Memahami pendapat seseorang, dalam hal ini opini publik tidak mudah. Karena itu adalah upaya membangun opini publik yang dibentuk oleh publik selektif, karena dalam semua masalah selalu ada setiap publik. Hubungan Masyarakat memainkan peran yang sangat penting dalam setiap lembaga atau lembaga, karena hubungan masyarakat merupakan salah satu upaya strategis dalam menciptakan citra positif atau negatif dalam suatu lembaga. Dalam hal ini humas memiliki hubungan luas. Peran humas dalam pengembangan pendidikan memiliki posisi yang sangat mendesak, terutama untuk menentukan pendidikan sesuai dengan keinginan semua pihak, terutama tuntutan pelanggan. Berkembangnya opini publik dengan beragam karakter semakin beragam, baik internal maupun eksternal membutuhkan solusi khusus dalam berkomunikasi dengan mereka. Kegiatan komunikasi organisasi adalah kegiatan komunikasi strategis yang perlu dilakukan oleh organisasi. Sebab hal ini berkaitan dengan pencitraan lembaga pendidikan itu sendiri.
\end{abstract}

Kata Kunci: Humas, Opini Public, Pencitraan lembaga Pendidikan

\begin{abstract}
The existence of public relations management is very important in an educational institution, especially in communication with the community to form a good opinion. Education is the biggest source of investment in developing and making people whole (insanul kamil). Understanding someone's opinion, in this case public opinion is not easy. Because it is the formation of public opinion formed by the selective public, because in all problems there is always every public. Public Relations plays a very important role in every institution or institution, because public relations is one of the strategic ways in creating a positive or negative image in an institution. In this case public relations has a broad relationship, and the role of public relations in the development of education has a very urgent position, especially in determining the direction of education in accordance with the wishes of all parties, especially customer demands. The development of public opinion with a variety of characters increasingly diverse, both internal and external requires special solutions in communicating with them. Organizational communication activities are strategic communication activities that need to be carried out by the organization. Because this is related to the image of the educational institution itself.
\end{abstract}

Keywords: Public Relations, Public Opinion, Imaging Educational Institutions 


\section{2 | Patrea Reola Pramungkas}

\section{Pendahuluan}

Pendidikan adalah aspek yang sangat penting dari implementasi hak asasi manusia, pelaksanaan hak-hak ini dilakukan oleh masing-masing negara untuk mencapai tujuan dan sasaran nasional negara yang bersangkutan. Indonesia adalah salah satu negara yang mengakui dan melindungi hak asasi manusia dalam pendidikan. Pendidikan adalah bidang investasi terbesar dalam mengembangkan dan membentuk manusia seutuhnya. Pendidikan diyakini akan mampu membentuk sumber daya manusia yang beradab dan berkualitas. ${ }^{1}$

Saat ini diskusi tentang hubungan masyarakat di lembaga pendidikan masih belum berfungsi dengan baik oleh lembaga pendidikan, terutama di lembaga pendidikan Islam. Ini tidak terlepas dari kurangnya informasi dan pengetahuan yang dimiliki oleh para manajer atau pelaksana di lembaga kecuali mungkin pada tingkat pendidikan tersier sudah ada staf atau petugas sendiri di departemen hubungan masyarakat. Fungsi hubungan masyarakat untuk lembaga pendidikan sangat penting. Karena dengan hubungan masyarakat yang baik, lembaga pendidikan dapat melanjutkan keberadaan lembaga mereka sehingga mereka dapat menggunakannya sebagai cara yang efektif untuk membuat lembaga mereka "ada" dan memiliki citra yang baik di masyarakat. Suatu lembaga pendidikan yang berjuang untuk mengembangkan dan mengembangkan harus mampu menciptakan citra positif (image) di hati masyarakat adalah suatu keharusan yang tidak boleh dilakukan, sehingga masyarakat mampu membuat keputusan untuk mendaftarkan anak-anak mereka dan berpartisipasi aktif berpartisipasi dalam pengembangan institusi pendidikan. Sehingga selain dengan pengembangan kualitas juga butuh kegiatan PR yang produktif berdasarkan visi dan misi yang jelas. ${ }^{2}$

Public Relations dalam suatu institusi pendidikan adalah rangkaian manajemen yang berkaitan dengan kegiatan hubungan institusi pendidikan dengan masyarakat yang dimaksudkan untuk mendukung proses belajar mengajar di institusi pendidikan sehingga dapat meningkatkan kualitas pembelajaran. Fungsi hubungan masyarakat di lembaga sekolah sesuai dengan Undang-Undang Republik Indonesia nomor 20 tahun 2003 bahwa "Sistem Pendidikan Nasional harus memastikan kesempatan yang sama untuk pendidikan, peningkatan kualitas , relevansi serta efisiensi manajemen pendidikan guna menghadapi tantangan berdasarkan tuntutan perubahan kehidupan lokal, nasional dan global sehingga perlu untuk merencanakan pendidikan secara terencana, terarah dan berkelanjutan". ${ }^{3}$

Sebagai makhluk sosial, manusia tidak terlepas dari bantuan orang lain. Karena itu manusia harus bekerja sama satu sama lain dari satu manusia

1Slamet Mulyadi, Perencanaan Humas Dan Usaha Membangun Citra Lembaga Yang Unggul, (Jurnal Studi Manajemen Pendidikan, 2.2, 2018), h. 125.

${ }^{2}$ Qoimah, Membangun Pelayanan Publik Yang Prima: Strategi Manajemen Humas Dalam Penyampaian Program Unggulan Di Lembaga Pendidikan, (Jurnal Manajemen Pendidikan Islam, I.2 2018), h. 193.

3Undang-Undang Republik Indonesia Nomor 23 Tahun 2003 Tentang Sistem Pendidikan Nasional, Pasal 8. 
ke manusia lainnya dalam berbagai bidang. Ini selain pekerjaan akan lebih ringan, itu juga akan membuatnya lebih mudah untuk menyelesaikan pekerjaan. Karena manusia hidup dengan manusia lain, hubungan baik dengan orang lain perlu dipertahankan dan dipelihara karena itu adalah salah satu syarat mutlak untuk menciptakan kehidupan yang damai dan harmonis. Dalam suatu organisasi lembaga pendidikan diperlukan kerja sama antara kepala sekolah dan seluruh karyawan, serta kerja sama dengan pihak luar, yaitu lembaga pendidikan lainnya. Dari sini, penting untuk mempelajari semua elemen dan semua hal yang berkaitan dengan PR.

Kegiatan public relations atau humas yang dikonseptualisasi dan dioperasikan oleh sebuah organisasi, meskipun pada hakikatnya mempunyai persamaan, dalam hal-hal tertentu memiliki perbedaan-perbedaan yang disebabkan oleh organisasinya yang berbeda. ${ }^{4}$ Ruang lingkup kehumasan berdasarkan ciri serta fungsinya seperti dijelaskan dimuka pada umumnya terklasifikasi menurut jenis organisasi yang pada garis besarnya humas pemerintah, humas perusahaan, dan humas internasional. Dengan demikian ruang lingkup public menyangkut hubungan public intern dan public ekstern yang ada sangkut pautnya dengan badan-badan yang bersangkutan. Seperti halnya human relations, public relations banyak dipraktekkan diberbagai organisasi untuk menunjang manajemen guna mencapai tujuannya secara efektif dan efisien. ${ }^{5}$ Pelaksanaan public relations itu lebih bertitik berat pada keterampilan membina hubungan antar manusia didalam dan diluar organisasi seraya mencegah timbulnya masalah. Sebagaimana penjelasan diatas bisa disimpulkan bahwa purel hanyalah terdapat dalam suatu organisasi, yang jelas strukturnya dan jelas pula adanya pemimpin dan yang dipimpin.

Strategi dalam ketatnya persaingan antar lembaga pendidikan, menuntut lembaga pendidikan untuk membangun citra yang semakin ketat haruslah didukung dengan strategi yang baik sehingga citra menarik minat konsumen SDM, dalam hal ini persaingan memperkokoh sumber daya manusia (SDM), dengan memperkuat bidang faslitas gedung dan sarana lainnya dan juga bidang pendanaan, serta memperkuat jaringan dari pada yang lainnya. Adanya peran yang begitu vital dalam lembaga pendidikan dalam bersaing dengan lembaga lain, tentunya diperlukan humas untuk membentuk citra baik dan mewujudkan visi misi lembaga pendidikan serta sebagai promosi. Peran Humas pada lembaga pendidikan umumnya masih dipandang sebelah mata, tidak sedikit lembaga pendidikan yang mengabaikan perannya seperti dibebani dengan tugas-tugas administrasi lembaga, mengantar undangan, melayani tamu dan kadang hanya sebagai pelengkap kestrukturan organisasi lembaga.

Seiring perkembangan zaman, paradigma peran humas mulai bergeser. Pada Era modern ini humas tidak hanya sekedar menghadiri

4Pelaksanaan Dakwah, 'Urgensi Public Relation dalam Pelaksanaan Dakwah, (AlAshlah, 3.12019$)$, h 51.

${ }^{5}$ Ira Nur Harini, Manajemen Hubungan Masyarakat Dalam Upaya Peningkatan Pencitraan Sekolah, (Jurnal Inspirasi Manajemen Pendidikan, Vol. 4 No. 4, April 2014, Hlm. 820, 4.4 2014), h 8-20. 


\section{4 | Patrea Reola Pramungkas}

undang dan mengantar surat saja. Humas saat ini harus mampu mengembangkan komunikasi dan kerjasama untuk mendapatkan citra yang baik (good will) dari stakeholder-nya. Terciptanya hubungan yang baik dengan publik, baik intern maupun ekstern dapat membentuk opini publik yang menguntungkan bagi lembaga pendidikan. Pembentukan Opini publik yang terus mengalami perubahan- perubahan informasi dituntut mampu menuntun opini publik sehingga terbentuk opini yang baik pada lembaga pendidikan dan juga informasi yang disampaikan humas haruslah tepat, akurat dan compatible. Terciptanya kepercayaan antara lembaga pendidikan dengan publik, maka akan memberikan nilai lebih pada pendidikan.

Kepercayaan yang di bangun pada public bukanlah hal yang mudah dilakukan. Lembaga pendidikan harus memiliki keterampilan berkomunikasi, diplomasi serta dapat menutupi kekurangan lembaga pendidikan dan dapat mengekpos bagi kelebihan lembaga pendidikan dalam pelaksanaannya. Oleh karena itu dalam memperoleh kepercayaan harus dilakukan terus menerus dalam jangka waktu yang lama sehingga terbentuk umpan balik informasi dari stakeholdernya sehingga terbentuk opini public yang bersimpati lembaga pendidikan.

Kelebihan dan keunggulan lembaga pendidikan harus dibangun dan ditonjolkan sehingga lembaga memiliki nilai lebih dibanding lembaga lain. Kepercayaan yang diperoleh oleh lembaga harus dipertahankan. Adapun proses mempertahankan citra positif bagi lembaga pendidikan tidak lepas dari kualitas dan kuantitas lembaga yang dapat dinilai oleh public.6 Penilaian ini dapat di lihat dari segi output (alumni), pelayanan yan baik serta pembinaan hubungan baik antara humas dan publik.7 Membangun kepercayaan dan mempertahankan kepercayaan publik teradap lembaga bukanlah hal yang mudah, keduanya perlu diupayakan sehingga citra yang baik dapat terbentuk dan terjamin ketahanannya.

Di era modern, kepercayaan yang diberikan oleh publik kepada institusi selalu bergeser. Kualitas dan kuantitas lembaga sebagai penyedia layanan pendidikan, harus memiliki terobosan baru dalam menghadapi persaingan global, untuk menjaga kelangsungan lembaga. 8 Terobosan dapat berupa pengembangan dalam semua aspek sehingga lembaga terus bergerak maju dengan beberapa perencanaan yang terorganisir dan juga evaluasi yang berkelanjutan. ${ }^{9}$

Kegiatan Humas pada hakikatnya kegiatan komunikasi. Namun berbeda dengan aktifitas komunikasi lainnya, kegiatan komunikasi dalam humas mempunyai ciri-ciri tertentu, disebabkan karena fungsi, sifat

${ }^{6}$ Saeful Kurniawan, Pengembangan Manajemen Mutu Pendidikan Islam Di Madrasah, (Al-Tanzim : Jurnal Manajemen Pendidikan Islam, 1.2 2017), 25-36.

${ }^{7}$ Anggit Grahito Wicaksono, Fenomena Full Day School dalam Sistem Pendidikan, (Komunikasi Pendidikan, 1.1 2017), h 12.

8Zamroni Hasan Baharun, Manajemen Mutu Pendidikan: Ikhtiar Dalam Meningkatkan Mutu Pendidikan Madrasah Melalui Pendekatan Balanced Scorecard (Tulungagung: Akademia Pustaka, 2017).

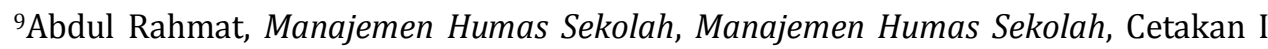
(Yogyakarta: Media Akademi, 2016). h. 12 
organisasi lembaga dimana Humas itu berada, sifat-sifat manusia yang terlibat, terutama public sebagai sasaran, faktor eksternal yang berpengaruh dan sebagainya bersifat khas. Kemudian sebagai salah satu upaya berusaha menciptakan persamaan (ide, paham, tingkah laku) merupakan kegiatan dasar public relations. Dalam hal ini public relations officer (PRO) harus senantiasa meluncurkan kegiatan komunikasinnya yang mencakup:

a. Komunikasi dengan Public Intern, yang meliputi:

- Hubungan dengan karyawan

- Hubungan dengan dengan pemegang saham (bagi perusahaan)

b. Komunikasi dengan Publik Ekstern yang meliputi:

- Hubungan dengan langganan

- Hubungan dengan masyarakat sekeliling

- Hubungan dengan pemerintah

- Hubungan dengan Pers.

Peran humas dalam lembaga pendidikan adalah salah satu komponen inti dan penting dalam manajemen pendidikan. Yang mana, proses manajemen hubungan masyarakat untuk pendidikan adalah proses perencanaan, implementasi, pengendalian, dan evaluasi program yang berpusat pada interaksi sosial lembaga dengan memaksimalkan potensi sumber daya. Tahap-tahap manajemen ini tidak dapat bergerak secara independen tanpa melibatkan fungsi-fungsi lain. Karena, masing-masing menjalankan fungsi manajerial tertentu, fungsi manajerial lainnya akan mengikuti sebagai tahap berikutnya. ${ }^{10}$ Peran humas dalam lembaga pendidikan ke depan, antara lain: ${ }^{11}$

a. Membina hubungan harmonis kepada publik di lingkungan lembaga seperti guru, staf administrasi, karyawan serta peserta didik, juga terkait hubungan kepada publik eksternal (di luar) lingkungan lembaga pendidikan, seperti orang tua peserta didik, masyarakat dan di luar instansi lembaga.

b. Membangun komunikasi dua arah kepada publik internal -eksternal dengan menyebar pesan, informasi dan publikasi hasil penelitian serta berbagai kebijakan yang telah ditetapkan oleh pimpinan.

c. Mengidentifikasi serta menganalisis opini atau persoalan, baik di lembaga pendidikan maupun masyarakat

d. Mampu mendengarkan keinginan atau aspirasi masyarakat.

e. Terampil dalam menerjemahkan kebijakan pimpinan dengan baik.

Opini publik berasal dari Opini Publik Inggris. Menurut Soenarjo, opini publik dalam bahasa Indonesia seringkali diterjemahkan sebagai "opini publik", sehingga publik diterjemahkan sebagai "umum", sedangkan opini diterjemahkan sebagai "opini".12 Menurut Seitel, opini publik terdiri dari dua komponen kata yaitu public dan opinion. Batasan publik adalah kelompok

${ }^{10}$ Muhammad Nur Hakim, Mengembangkan Lembaga Pendidikan: Studi Kasus Di SMK Negeri 1 Dlanggu Mojokerto , (Jurnal Manajemen Pendidikan Islam, 4.1 2019), h. 125.

${ }^{11}$ Elfridawati Mai Dhuhani, Manajemen Humas Dalam Meningkatkan Mutu Madrasah Studi Kasus Di Madrasah Ibtidiyah Terpadu (Mit) As-Salam Ambon, (Jurnal Al- i l t i z a M, 1.1 2016), h. 40.

12Saleh \& Ardianto Soemirat, Dasar-Dasar Publik Relations, (Bandung: PT Remaja Rosdakarya, 2005), h. 106. 


\section{6 | Patrea Reola Pramungkas}

yang memiliki minat yang sama dalam masalah tertentu. Opini adalah ekspresi sikap terhadap topik tertentu. ${ }^{13}$

Opini publik adalah kumpulan opini individu tentang masalahmasalah tertentu yang mempengaruhi sekelompok orang (masyarakat). Pendapat lain menyatakan bahwa opini publik mewakili suatu perjanjian, dan perjanjian tersebut dimulai dengan sikap masyarakat terhadap masalah yang masih menjadi tanda tanya.

Pendapat umum menurut Kamus Besar Bahasa Indonesia (KBBI) adalah pendapat kebanyakan orang. Teori dalam opini publik pada umumnya memberi gambaran terkait peran yang dimainkan oleh berbagai komunikasi dalam pembentukan opini publik. Menurut Davis, teori-teori dalam opini publik dapat dikelompokkan menjadi empat era, yaitu era teori opini publik awal, era penelitian empiris, era aspek kognitif dari teori media, dan era saat ini teori normatif demokratis. Era awal teori opini publik adalah era pertama teori opini publik yang dikembangkan pada akhir abad ke-18. Teori opini publik di era ini sebagian besar adalah teori normatif yang memandang legitimasi atau oposisi sebagai akibat dari perubahan sosial-politik yang pada saat itu mulai berkembang di Amerika Serikat dan Eropa.14

rlandia dan Protho menyebutkan bahwa opini publik adalah ungkapan sikap tentang masalah masyarakat. Definisi tersebut meliputi tiga aspek: (1) Ekspresi, (2) Adanya masalah yang menyebabkan pro dan kontra, (3) Komunitas atau melibatkan komunitas.15 Jadi, penulis menyimpulkan bahwa opini publik itu adalah sikap masyarakat berupa tanggapan mengenai suatu masalah yang dapat menimbulkan pro dan kontra dalam masyarakat itu sendiri. Teori opini publik di era sekarang cenderung mengekspresikan rasa optimisme dan pesimisme sebagai akibat dari keterlibatan publik yang besar dalam pemerintahan. Termasuk dalam teori awal opini publik ialah teori masyarakat massa, teori utilitarian, teori sikap, teori propaganda, , dan teori pers.

Sementara itu, era penelitian empiris dimulai dengan perdebatan tentang konsep opini publik serta perannya dalam demokrasi kita. Perbedaan konsep opini publik antara Dewey dan Lippmann menyebabkan pengembangan berbagai teknik penelitian untuk mengukur opini publik dan menciptakan beragam teori empiris opini publik yang dikemukakan para ahli. Hal ini ditandai oleh berbagai studi awal tentang efek media massa terhadap opini publik oleh Carl I. Hovland dan Paul F. Lazarsfeld. Di era ini, opini publik ditafsirkan sebagai fenomena yang dibentuk melalui beragam proses komunikasi. Teori empiris opini publik di era ini meliputi teori aliran informasi kepada publik serta teori tentang efek terbatas dari media massa.

Era ketiga teori opini publik adalah kembalinya aspek kognitif dalam teori media pada 1970-an. Teori media di era ini lebih banyak dipengaruhi oleh psikologi kognitif. Teori opini publik di era ini mencakup teori efek

\footnotetext{
${ }^{13}$ Saleh Soemirat \& Ardianto. Dasar-Dasar Publik Relations, (Bandung: PT Remaja Rosdakarya, 2005), hal. 106.

14Pelaksanaan Dakwah, Urgensi Public Relation dalam Pelaksanaan Dakwah, AlAshlah, 3, 2019), h. 51

15Saleh Soemirat \& Ardianto. Dasar-Dasar Publik Relations, hal. 106.
} 
media massa seperti teori pengaturan agenda, teori kesenjangan pengetahuan, dan teori spiral of silence. Dan, akhirnya, era teori normatif demokrasi. Di era ini, teori normatif demokrasi telah berubah karena perkembangan teori liberalisme atau demokrasi pluralistik yang berdampak pada teori-teori opini publik. Termasuk dalam era teori normatif demokrasi saat ini adalah teori domain publik dan teori demokrasi partisipatif.

Dalam perkembangan selanjutnya, pembentukan sistem politik, individu dan kelompok akan bersaing untuk mengejar kepentingan politik dan ekonomi, termasuk dalam pendidikan. Persaingan bebas untuk beberapa lembaga pendidikan dapat terjadi melalui pertempuran ide, ide di mana berbagai minat dipromosikan dan pandangan mayoritas terbentuk yang mengarah pada munculnya pilihan untuk memenuhi pilihan pemangku kepentingan (pengguna).

Proses pembentukan opini dapat terlahir dengan cara pandang masyarkat mengenai suatu hal persoalan, dimana persoalan yang terjadi di lingkungan masyarakat yang sama. Opini terbentuk tergantung, pada pengetahuan dan pendidikan masing masing pihak. ${ }^{16}$ Dalam proses pembentukan opini terdapat factor penentu yang dipengaruhi oleh :

a. Latar belakang budaya, kebiasaan dan adat istiadatyang dianut seseorang/masyarakat

b. Pengalaman masa lalu seseorang atau kelompok yang tertentu menjadi landasan atau pendapat atau pandangan.

c. Nilai-nilai yang dianut )moral, etika, dan keagamaan yang dianut atau nilai-nilai yang belraku dimasyarakat)

d. Berita-berita dan pendapat yang berkembang yang mempunyai pengaruh terhadap pandangan seseorang.

Pencitraan awal mulanya digunakan dalam dunia perindustrian utamanya berkaitan dengan suatu produk industri. Seiring waktu, merambah pada dunia pendidikan yang dipicu oleh arus globalisasi. Citra menurut Lawrence L. Steinmetzs dalam Siswanto Sutojo, diartikan sebagai Pancaran atau reproduksi jati diri atau bentuk orang perorangan, benda atau organisasi/lembaga. Pendapat lain yang dikemukakan oleh Sandra Oliver, citra lebih dekat dengan pencitraan yaitu anggapan yang muncul dalam diri konsumen disaat mengingat suatu produk tertentu. Mindset itu dapat muncul dalam bentuk pemikiran atau kesan tertentu yang dikaitkan dengan suatu merek atupun produk. Bentuk pikiran dalam seseorang tersebut kemudian dikonsepkan berdasarkan pengklasifikasian tertentu berdasar daya dukung, ingatan, serta keunikan tertentu pada produk. Sehingga Jenis anggapan itu meliputi antribut, manfaat dan sikap. ${ }^{17}$

Dalam dunia pendidikan, Pencitraan merupakan bentuk kesan yang ditangkap oleh para konsumen yang diperankan oleh para masyarakat, orang tua murid maupun pihak-pihak yang menggunakan jasa pada pendidikan. Sehingga Atribut jasa yang dimaksudkan dalam pendidikan adalah layanan

${ }^{16}$ Hadi Yusri, Opini Publik Terhadap Program Siaran Berita Di Radio Pemerintah Kabupaten Siak, (Fisip, 2.2 2015), h. 5.

17 Lawrence L. Steinmetzs, "Public Relations Strategy", diterjemahkan oleh Siswanto Sutojo dengan judul: Membangun Citra Perusahaan (Jakarta: PT Damar, 2010), h. 73. 


\section{8 | Patrea Reola Pramungkas}

yang diberikan pihak sekolah terhadap proses belajar mengajar. Sementara atribut produk adalah hasil dari layanan lembaga pendidikan terhadap siswa. Oleh karean itu kemudian muncul ide atau kesan terhadap produk yang dihasilkan dengan penamaan ; citra yang baik atau citra buruk. Dari citra baik akan muncul seperti public understanding (pengertian publik), public confidence (kepercayaan publik terhadap lembaga atau organisasi), public support (adanya unsur dukungan dari dari publik), dan public cooperation (kerjasama dari publik terhadap lembaga). Begitu juga sebaliknya.

Dari penjelasan diatas dapat disimpulkan bahwa bentuk komunikasi humas/Public Relation (PR) adalah sangat menentukan terhadap citra organisasi/lembaga dalam menjalankan komunikasi verbal dan non verbal perusahaan/lembaga. Ada beberapa upaya mengangkat citra lembaga. Pertama secara eksternal yaitu dilakukan melalui dua cara (secara koersif (paksaan) dan persuasive (membujuk),). Model paksaan diartikan sebagai bentuk kewenangan lembaga yang memuat aturan aturan yang mengikat bagi publik. Model upaya persuasive (membujuk) adalah serangakaian upaya komunikasi yang berfungsi mempengaruhi psikologis publik melalui beberapa kegiatan seperti penyampaian informasi secara lisan, ceramah, propaganda, lobby yang ditujukan mempengaruhi cara pandang publik.

Oleh karena itu Persepsi publik terhadap lembaga tergantung pada siapa humas dan bagaimana karakter humas sebagai figur perwakilan lembaga yang menjadi tanggung jawabnya. Posisi humas dalam lembaga pendidikan harus seseorang yang memiliki pengetahuan luas, berkarakter, serta figure yang mampu meyakinkan public. Di samping itu humas seharunya mempunyai sikap optimis, obyektif, mampu menganalisis dan merasionalkan permasalahan Perusahaan ataupun lembaga pendidikan dalam membangun citra..$^{18}$

Adapun citra merupakan bagaimana pihak lain memandang perusahaan, seseorang, suatu komite atau suatu aktifitas. Secara garis besar citra adalah perangkat keyakinan, ide, dan kesan seseorang terhadap suatu objek tertentu. yang dimaksud membangun citra adalah bagaimana membentuk cara pandang terhadap lembaga pendidikan baik secara eksternal maupun internal melalui aktifitas dan langkah yang terukur. secara konsetual strategi humas dalam membangun citra lembaga adalah serangkaian cara yang didasarkan pada situasi kondisional untuk membangun opini publik guna memperoleh citra yang baik bagi lembaga.19

Tugas Manajerial humas Menurut F. Rachmadi, pertama penemuan fakta (fact finding), perencanaan (planning), komunikasi/ pelaksanaan (actuating), dan evaluasi (evaluating). Adapun penjelasannya adalah sebagai berikut, pertama Reseacrh - Penemuan fakta (Fact Finding) Penemuan fakta dilakukan untuk mengetahui bagaimana situasi dan kondisi yang terjadi di lapangan dan apakah situasi dan pendapat dalam masyarakat menunjang atau justru menghambat kegiatan lembaga pendidikan. Ada beberapa proses

18Uud Wahyudin dan Dedi Rumawan Erlandia, 'Peran Humas Pemerintah Dalam Pemasaran City Branding, 2, 2018), h 167.

${ }^{19}$ Anshari Hannah Mahfuzhah, Media Publikasi Humas Dalam Pendidikan, (AlTanzim : Jurnal Manajemen Pendidikan Islam, 2.2, 2018), h. 137-49. 
yang harus dilakukan oleh seorang humas yaitu Memperhatikan berbagai kejadian atau perkembangan sosial, politik maupun ekonomi yang berkaitan secara langsung atau tidak langsung berhubungan dengan lembaga atau perusahaan. Mengumpulkan, menganalisa dan menyajikan berbagai macam data untuk diolah menjadi informasi bagi publik. Kedua; Perencanaan dan Mengambil Keputusan (Planning - Decision).

Pada tahap ini yang merupakan kelanjutan dari tahap pertama. Adanya penemuan fakta bagi lembaga pendidikan, seorang humas merencanakan yang akan diterapkan pada lembaga pendidikan seharusnya bertindak. Seorang humas harus memperhatikan factor faktor psikologis, sosiologis, keadaan sosial, ekonomi dan politik dalam skala tertentu.20 Tahap ini akan memberikan dampak kehati-hatian dan membuat perancaan yang jelas dalam jangka waktu tertentu bagi lembaga pendidikan untuk membuat regulasi ke depannya. Ketiga ; Komunikasi - Pelaksanaan (Communication Action). Fungsi komunikasi adalah sebagai penyampai informasi menyeluruh bagi publik dalam regulasi yang dibuat oleh lembaga pendidikan kepada publik. Oleh karena itu informasi yang disampaikan kepada publik harus betul-betul akurat, kredibel dan dapat dipertanggungjawabkan. Keempat ; Evaluasi (Evaluation).

Evaluasi merupakan faktor yang sangat krusial dilakukan oleh lembaga pendidikan. Tahap ini digunakan untuk memperoleh informasi utuh dari hasil dari kegiatan yang dilakukan, informasi yang disebarkan, kebijakan yang dibuat dan juga sebagai refrensi untuk melakukan tindakan-tindakan yang akan dilakukan selanjutnya. Ada beberapa keuntungan ketika evaluasi dilakukan.21 Menurut Ngurah putra, keuntungan evaluasi program yang dilakukan seperti humas dapat mempertahankan program-programnya dan terarah, Setiap kegiatan dan kebijakan yang dibuat dapat dipertanggungjawabkan, meningkatkan efisensi sarana prasarana dan profesionalisme SDM, fasilitas sarana prasarana terus meningkat, dan lain sebagainya.

Strategi merupakan sebuah cara untuk menjaga kelangsungan lembaga dan mewujudkan harapan lembaga, Menurut Jack Trout dalam Suyanto yang dimaksud dengan inti strategi adalah bagaimana bisa bertahan hidup dalam dunia kompetitif, membuat persepsi yang baik di benak konsumen, berbeda, mengenali kekuatan serta kelemahan pesaing, memiliki spesialisasi, mampu menguasai satu kata di kepala. Oleh karena itu suatu lembaga seharsunya melakukan langkah-langkah untuk membuat konsumen (user) mempercayai secara utuh mulai dari A $-\mathrm{Z}$. begitu juga lembaga dituntut untuk mengetahui strategi dalam menghadapi persaingan (competitive ners). Dengan meengetahui kelebihan dan kelemahan dari lembaga, maka akan di ketahui langkah-langkah yang akan dilakukan untuk menghadapi persaingan. Kelemahan dan kelebihan dapat terjdi pada manajemen operasional, Sumber Daya Manusia, serta manajemen financial dan manajemen sytemnya.

${ }^{20}$ Abdul Rahmat, Manajemen Humas Sekolah, Manajemen Humas Sekolah, $h 46$

21Slamet Mulyadi, Perencanaan Humas Dan Usaha Membangun Citra Lembaga Yang Unggul, h. 125 
Ruslan menekankan alternatif yang optimal yang dipilih dan ditempuh guna mencapai tujuan public relations dalam kerangka suatu rencana public relations. optimalisasi yang di tawarkan oleh Ruslan dalam lembaga pendidikan senada dengan tawaran dari Jack Trout, yaitu dalam mengotimalkan pada manajemen operasional, Sumber Daya Manusia, serta manajemen financial dan manajemen system. Oleh karena itu strategi dapat diatikan sebagai langkah dalam mempertahankan diri, mengenali kelemahan dan kekuatan untuk bersaing dan membuat persepsi baik pada public untuk mewujudkan tujuan lembaga secara optimal.

Hubungan masyarakat atau yang kita kenal sebagai humas merupakan sosok figur yang menjalin hubungan dengan masyarakat melalui cara yang terencana atau dapat dikatan humas merupakan rangkaian kegiatan yang terorganisir sedemikian rupa sebagai rangkaian kampanye atau program terpadu. Semuanya itu berlangsung secara berkesinambungan dan teratur. Humas sebagai sosok figur yang menjalankan program terpadu yang berkesinambungan dengan melihat realita kondisi dimasyarakat, merupakan bekal bagi lembaga pendidikan yang ditujukan untuk menumbuhkan hubungan baik antara segenap stakeholder dan komponen pada suatu lembaga pendidikan. Dampak dari ini akan memberikan pengertian, menumbuhkan motivasi dan partisipasi dari user. Dan secara umum, bertujuan untuk menumbuhkan dan mengembangkan pengertian dan kemauan baik publiknya dan memperoleh opini publik yang simbiosis mutualisme. Hal ini sejalan dengan implementasi dari tujuan jangka panjang bagi institusi lembaga pendidikan sebagaimana pemaparan Stephen Robbins sebagai bahwa penentuan tujuan jangka panjang organisasi dan memutuskan tindakan serta mendapatkan sumber yang diperlukan untuk mencapai tujuan organisasi (lembaga pendidikan) .22

Dalam skala nasional disebutkan bahwa tujuan jangka panjang akan terwujud jika adanya kesinambungan antara penerimaan publik melalui pemahaman, pengertian dan pemahaman baik dari publik yang dilakukan perusahaan yang dalam hal ini adalah peran humas. Perencanaan lembaga yang dilakukan dengan sistem yang baik dan berkelanjutanakan membentuk opini publik yang konsisten.23 Rosady Ruslan mengatakan bahwa strategi public relation atau humas merupakan alternatif optimal yang dipilih untuk ditempuh guna mencapai tujuan public relation dalam suatu kerangka acuan dalam rencana lembaga pendidikan. Ada dua komponen Strategi yang harus dilakukan oleh humas, yaitu komponen sasaran dan komponen sarana. fokus komponen sasaran umumnya melalui upaya segmentasi yang dilandasi oleh seberapa jauh sasaran tersebut menyandang opini bersama (common opinion), potensi akan polemik, dan pengaruhnya bagi masa depan lembaga yang menjadi perhatian sasaran khusus untuk membidik sasaran khusus yang di sebut publik sasaran (target public) atau juga komponen sarana.

22Slamet Mulyadi, Perencanaan Humas Dan Usaha Membangun Citra Lembaga Yang Unggul, h. 125.

${ }^{23}$ Mifrohatul Musyarrofah, Peran Humas Dalam Pengembangan Pendidikan Tinggi, Jurnal Idaarah, 2.1, 2018), h 19. 
Komponen sarana ini berfungsi untuk mengarahkan pada keutungan lembaga pendidikan.

Humas dalam mencapai target strateginya didasari pada opini bersama, polemik publik, dan seberapa pengaruh yang diberikan oleh humas bagi masa depan lembaga. Konsep target ini sejalan dengan pemaparan Stoner, Freeman, dan Gilbert dalam Tjiptono Fandy dapat didefinisikan berdasarkan dua perspektif, yaitu perspektif apa yang organisasi ingin lakukan yang mengacu pada program untuk menentukan dan mencapai tujuan organisasi dan mengimplementasikan misi lembaga pendidikan. 24

Ada beberapa pandangan dalam organisasi dalam mengakomodir terkait dengan pola tanggapan atau respon organisasi terhadap lingkungannya sekitar, untuk mencapai tujuan lembaga dan mengetahui seberapa besar respon publik atas apa yang dilakukan oleh humas untuk membangun citra perusahaan/lembaga. Yulianita mengatakan bahwa tujuan yang ingin di capai sebagai berikut yaitu menciptakan, memelihara, meningkatkan citra yang baik serta memperbaiki citra jika tidak baik. 25

Berdasarkan penjelasan diatas, strategi humas untuk mempengaruhi opini publik dan untuk mewujudkan pengertian dan kemauan baik (good will) publiknya serta menciptakan citra yang baik dapat dijelaskan sebagai berikut. Pertama; Menjelaskan tujuan-tujuan organisasi kepada publik terkait visi, misi serta peran lembaga di wilayah publik. Oleh karena itu humas harus memahami semua tugas baik manajemen, sistem serta operasionalnya lembaga pendidikan tersebut. Kedua ; sebagai informan lembaga pendidikan yang dituntut harus mampu memperlancar arus informasi yang masuk dan keluar terkait beberapa pemberitaan dalam skala lokal maupun nasional. Dalam pelaksanaannya informasi yang disampai akurat, kompateble serta profesional dalam penyampaian kepada publik. Ketiga ; Pihak manajemen humas harus visioner melihat peluang dan memiliki kemampuan untuk memprediksi masa depan atau memprediksi suatu secara tepat. Prediksi ini harus didasarkan kepada pengetahuan akan data atau sumber informasi aktual dan faktual yang menyangkut kepentingan lembaga pendidikan maupun publik.

Dampak dari itu semua akan bermura pada kualitas dan kuantitas lembaga pendidikan dapat disandingkan dengan lembaga-lembaga pendidikan di dunia, dan menghasilkan output yang dapat berkontribusi pada masyarakat publik.

\section{Metode}

Penelitian merupakan penelitian kepustakaan (Library Research), data-data kepustakaan digunakan untuk mendapatkan teori kemudian dikaji dan ditelaah untuk memperoleh konsepsi untuk mendapatkan hasil yang objektif. Penelitian menggunakan pendekatan konten isi untuk merekonstruksi secara sistematis, akurat dan objektif. Pengumpulan data

${ }^{24}$ Slamet Mulyadi, Perencanaan Humas Dan Usaha Membangun Citra Lembaga Yang Unggul, h. 125.

${ }^{25}$ Abdul Rahmat, Manajemen Humas Sekolah, Manajemen Humas Sekolah, h 46 
menggunakan teknik kepustakaan dalam mencari data berupa buku-buku, catatan-catatan, notulen, surat kabar, agenda dan sebagainya.

\section{Peran Humas Membentuk Opini Publik dalam Upaya Pencitraan Lembaga Pendidikan}

Masyarakat sebagai pemakai bagi media massa, dipandang sebagai masyarakat yang tidak teraturdan tidak tahu apa-apa sehingga mudah untuk diperintah oleh para elit politik yang tak bermoral dan yang akan melakukan manipulasi opini publik untuk kepentingan elit tertentu. Oleh karena itu dalam teori Propaganda efek keperkasaan media menggiring opini publik pada hal-hal yang negatif. Komunikasi yang akurat, benar, dan kompatible dalam media sangat dijunjung tinggi dalam etika pers.

Dalam berkomunikasi pada media massa melibatkan tiga unsur pengirim yang disebut (sender), media komunikasi (media massa) dan penerima (receiver).26 Hal-hal positif dan negatif dalam konten (isi) komunikasi bergantung pada ketiga unsur diatas. Jika sender, media, maupun reciever tidak berkompeten atau pesan nya tidak jelas, sehingga si penerima tidak akan memahami makna dari tanda-tanda yang diberikan, dan proses komunikasi akan mengalami kegagalan. Begitu juga sebaliknya.

Sebagai reciever, humas juga dituntut untuk memahami hal tersebut. Ada beberapa Model public relations yang digunakan dalam model komunikasi public relations. James E. Grunig dan Todd Hunt dalam Ngurah, mengelompokkan model tersebut ke dalam empat model, sebagai berikut; pertama ; Press Agentry. Presss agency memiliki fungsi untuk propaganda, informasi bergerak satu arah. 27Arah yang dimaksud dari organisasi menuju ke publik opinion. Dapat disebut juga dengan promosi atau publisitas. keterlibatan organisasi sangat penuh, informasi yang disebarkan seringkali tidak lengkap. Sehingga mengakibatkan kerugian pada pihak lain. Kedua ; Public Information, bertujuan untuk memberi tahu kepada publik dan bukan untuk promosi dan publisitas. Alur komunikasinya masih tetap satu arah. Secara umum fungsi public relations sebagai pemberita (wartawan) dari dalam organisasi, dan juga sebagai pelapor informasi tentang lembaga/organisasi tersebut. Model ini lebih objektif dibanding press agency dalam informasi. ketiga ; Two-way Asymmetric disebut juga model asimetris dua arah. Humas atau praktisi public relations berperan sebagai mediator antara organisasi dan publik. Model ini menerapkan riset ilmu sosial dalam penyampaian informasi untuk meningkatkan efektivitas persuasi dari informasi yang diberikan. Model ini sangat baik digunakan pada organisasi ilmiah atau science. Adapun karakter utama model ini adalah perusahaan yang ditantang untuk melakukan dialog langsung dengan pemangku kepentingan (regulasi). Dalam proses komunikasi terjadi saling fied-back antara ketiganya, meskipun terjadi beberapa hal yang tidak sesuai.

\footnotetext{
${ }^{26}$ Husnan Abrori, Humas Sebagai Method of Communication Dalam Membentuk Image Madrasah, (Al-Tanzim : Jurnal Manajemen Pendidikan Islam, 2.2 2018), h. 160-66.

27I Gusti Ngurah Putra, Manajemen Hubungan Masyarakat, (Yogyakarta:Univ Atmajaya, 1999), h. 285.
} 


\section{Kesimpulan}

Peran Humas yang begitu vital dalam lembaga pendidikan dalam bersaing dengan lembaga lain untuk memperoleh kepercayaan harus dilakukan terus menerus dalam jangka waktu yang lama sehingga terbentuk umpan balik informasi dari stakeholdernya sehingga terbentuk opini public yang bersimpati lembaga pendidikan. Kelebihan dan keunggulan lembaga pendidikan harus dibangun dan ditonjolkan sehingga lembaga memiliki nilai lebih dibanding lembaga lain menciptakan persamaan (ide, paham, tingkah laku) merupakan kegiatan dasar public relations melaksanakan fungsi manajerial tertentu maka fungsi manajerial yang lainnya akan mengikuti sebagai tahap selanjutnya strategi humas dalam membangun citra lembaga adalah serangkaian cara yang didasarkan pada situasi kondisional untuk membangun opini publik guna memperoleh citra yang baik bagi lembaga, mempertahankan program-programnya dan terarah Kelemahan dan kelebihan dapat terjdi pada manajemen operasional, Sumber Daya Manusia, serta manajemen financial dan manajemen sytemnya strategi dapat diatikan sebagai langkah dalam mempertahankan diri, mengenali kelemahan dan kekuatan untuk bersaing dan membuat persepsi baik pada public untuk mewujudkan tujuan lembaga secara optimal. Hal ini bertujuan untuk meningkatkan, menumbuhkan dan mengembangkan pengertian dan kemauan baik (good will) publik serta memperoleh opini yang simbiosis mutualisme.

\section{Daftar Pustaka}

Abrori, Husnan. 2018. Humas Sebagai Method of Communication Dalam Membentuk Image Madrasah, Al-Tanzim : Jurnal Manajemen Pendidikan Islam, 2.

Baharun, Zamroni Hasan. 2017. Manajemen Mutu Pendidikan: Ikhtiar dalam Meningkatkan Mutu Pendidikan Madrasah Melalui Pendekatan Balanced Scorecard, Tulungagung: Akademia Pustaka.

Dakwah, Pelaksanaan. 2019. Urgensi Public Relation dalam Pelaksanaan Dakwah, Al-Ashlah, 3.

Dhuhani, Elfridawati Mai Dhuhani. 2016. Manajemen Humas Dalam Meningkatkan Mutu Madrasah Studi Kasus Di Madrasah Ibtidiyah Terpadu (Mit) As-Salam Ambon, Jurnal Al- i l t i z a M, 1.

Hakim, Muhammad Nur. 2019. Mengembangkan Lembaga Pendidikan: Studi Kasus Di Smk Negeri 1 Dlanggu Mojokerto, Jurnal Manajemen Pendidikan Islam, 4.

Harini, Ira Nur. 2014. Manajemen Hubungan Masyarakat dalam Upaya Peningkatan Pencitraan Sekolah, Jurnal Inspirasi Manajemen Pendidikan, Vol. 4 No. 4.

Kurniawan, Saeful. 2017. Pengembangan Manajemen Mutu Pendidikan Islam di Madrasah, Al-Tanzim : Jurnal Manajemen Pendidikan Islam, 1.

Lawrence L. Steinmetzs. 2010. Public Relations Strategy diterjemahkan oleh Siswanto Sutojo dengan judul: Membangun Citra Perusahaan, Jakarta: PT Damar. 
Mahfuzhah, Anshari Hannah. 2018. Media Publikasi Humas Dalam Pendidikan, Al-Tanzim : Jurnal Manajemen Pendidikan Islam, 2.

Mulyadi, Slamet. 2018. Perencanaan Humas dan Usaha Membangun Citra Lembaga yang Unggul, Jurnal Studi Manajemen Pendidikan, 2.

Musyarrofah, Mifrohatul. 2018. Peran Humas Dalam Pengembangan Pendidikan Tinggi, Jurnal Idaarah, 2.

Putra, I Gusti Ngurah. 1999. Manajemen Hubungan Masyarakat, Yogyakarta: Univ Atmajaya.

Qoimah. 2018. Membangun Pelayanan Publik yang Prima: Strategi Manajemen Humas dalam Penyampaian Program Unggulan di Lembaga Pendidikan, Jurnal Manajemen Pendidikan Islam, I.

Rahmat, Abdul. 2016. Manajemen Humas Sekolah, Manajemen Humas Sekolah, Cetakan I, Yogyakarta: Media Akademi.

Soemirat, Saleh \& Ardianto. 2005. Dasar-Dasar Publik Relations, Bandung: PT Remaja Rosdakarya.

Undang-Undang Republik Indonesia Nomor 23 Tahun 2003 Tentang Sistem Pendidikan Nasional, Pasal 8.

Wahyudin, Uud dan Dedi Rumawan Erlandia. 2018. Peran Humas Pemerintah Dalam Pemasaran City Branding, 2.

Wicaksono, Anggit Grahito. 2017. Fenomena Full Day School Dalam Sistem Pendidikan, Komunikasi Pendidikan, 1.

Yusri, Hadi. 2015. Opini Publik Terhadap Program Siaran Berita Di Radio Pemerintah Kabupaten Siak, Fisip, 2. 